\title{
Evaluation of Oxidative Stress Index and Some Biochemical Parameters in Neonatal Calves with Diarrhea
}

\section{Enes Akyüz ${ }^{1}$ and Abdulsamed Kükürt ${ }^{2 *}$}

${ }^{1}$ Department of Internal Medicine, Kafkas University, Turkey

${ }^{2}$ Department of Biochemistry, Kafkas University, Turkey

*Corresponding Author: Abdulsamed Kükürt, Faculty of Veterinary Medicine, Department of Biochemistry, Kafkas University, Turkey.
Received: July 20, 2021

Published: August 31, 2021

(C) All rights are reserved by Enes Akyüz and

Abdulsamed Kükürt.

\section{Abstract}

The aim of this study was to evaluate the total oxidant/antioxidant (TOC/TAC), oxidative stress index (OSI), and alanine aminotransferase (ALT), aspartate aminotransferase (AST), creatinine (CREA), and UREA levels in neonatal calves with diarrhea. In the study, 15 calves (0-10 days old Simmental, Swiss brown, or hybrid) brought to the clinic with the complaint of diarrhea formed the disease group. 15 healthy calves under the same care/feeding conditions formed the control group. TAC and TOC concentrations were measured by commercial kits. OSI results were calculated with the formula in which TOC and TAC results were proportioned. Serum ALT, AST, CREA, and UREA concentrations were measured with an autoanalyzer. The findings showed that TAC and TOC concentrations were affected by clinical diarrhea. Thus, it increased the oxidative stress index (OSI) $(p<0.001)$. Also, the ALT, AST, CREA, and UREA levels of diarrheal calves were found to be significantly higher than the levels of healthy calves. Consequently, it was observed that the oxidative damage in diarrhea caused an increase in OSI levels.

Keywords: Neonatal Calves; Diarrhea; Oxidative Stress; Oxidant; Antioxidant; OSI

\section{Introduction}

Diarrhea, which is one of the most important problems of cattle breeding in the world, is most common in calves in the neonatal period [1]. The neonatal period is used to define the 28 days following birth and is the period in which the most intense diseases and deaths occur in calves. Diseases occurring in calves during this period cause significant economic losses. These economic losses are the cost of treatment, loss of yield, and decrease in potential breeding stock, as well as newborn calf deaths [2-4]. It is known that many factors and factors play a role in the etiology of neonatal calf diarrhea. The most important of these are negative environmental factors, maternal reasons, unsuitable care/feeding conditions, and the calf's inability to receive colostrum. In addition, the main parasitic, viral, fungal, and bacterial agents among infectious agents constitute the source of neonatal diarrhea [5-8].
Oxidative stress is defined as an imbalance between the number of antioxidants and reactive oxygen species or reactive nitrogen species in a biological system. Reactive oxygen species (ROS) and reactive nitrogen species (RNS) are byproducts of various cellular processes, including aerobic metabolism. For example, nitric oxide (NO·), which is an RNS, is produced from 1-arginine by nitric oxide synthase and then reacts with superoxide (02--) to form peroxynitrite (ONOO-) [9-12]. These reactive oxygen/nitrogen species (RONS), that is, hydroxyl, superoxide anion, nitric oxide, and nitrosyl anion molecules, are highly reactive due to their unpaired valence electrons [10]. Normally, RONS have involved in cell signaling (redox signaling) pathways, thiol switches, regulation of inflammatory cytokines, growth factors, etc. They have important biological roles in many cellular events such as [13]. Under normal physiological conditions, the balance between the cellular level of RONS and antioxidants is maintained. However, when the redox balance is 
disturbed, these powerful oxidants (free radicals) can have harmful effects. These bad effects are ultimately caused by unregulated oxygen and nitrogen-containing free radicals, which attack different cells and damage DNA, protein, and lipids $[9,13]$.

\section{Aim of the Study}

The aim of this study was to evaluate the total oxidant/antioxidant (TOC/TAC), oxidative stress index (OSI), and alanine aminotransferase (ALT), aspartate aminotransferase (AST), creatinine (CREA), and UREA levels in neonatal calves with diarrhea.

\section{Materials and Methods}

This study was carried out after approval from Kafkas University Animal Experiments Local Ethics Committee (KAÜ-HADYEK/2021-118). Biochemical analyzes were carried out in the laboratories of the Department of Internal Medicine and Biochemistry of the Faculty of Veterinary Medicine of Kafkas University.

\section{Animals}

In the study, 15 calves (0-10 days old Simmental, Swiss brown, or hybrid) brought to the clinic with the complaint of diarrhea formed the disease group. 15 healthy calves under the same care/ feeding conditions formed the control group.

\section{Blood samples}

Blood samples $(8.5 \mathrm{~mL})$ were collected into gel serum tubes (BD Vakutainer ${ }^{\circledR}, \mathrm{BD}, \mathrm{UK}$ ) from the Vena jugularis with the help of a holder and compatible sterile needle tip (Vacuette ${ }^{\circledR}$, Greiner BioOne GmbH, Austria). Serum samples were obtained by centrifugation at $3000 \mathrm{rpm}$ for 10 minutes (Hettich Rotina $380 \mathrm{R}^{\circledR}$, Hettich, Germany) after the blood samples were kept at room temperature for approximately one hour. Serum samples were stored at $-20^{\circ} \mathrm{C}$ until analysis.

\section{Biochemical analyzes}

- Total antioxidant capacity measurement (TAC): TAC was measured by commercial kits (Total Antioxidant Status Assay Kit ${ }^{\circledR}$, Rel Assay Diagnostic, Turkey) [14] and results are given as mmol Trolox equiv./L.
- Total oxidant capacity measurement (TOC): TOC was measured by commercial kits (Total Oxidant Status Assay Kit ${ }^{\circledR}$, Rel Assay Diagnostic, Turkey) [15] and results are given as $\mu \mathrm{mol}$ $\mathrm{H}_{2} \mathrm{O}_{2}$ equiv./L.

- $\quad$ Oxidative stress index (OSI): Units of TAC were converted into $\mu \mathrm{mol} / \mathrm{L}$, and OSI was calculated using the formula OSI = (TOC/ TAC)*100 [16].

- $\quad$ Serum ALT (IU/L), AST (IU/L), CREA (mg/dL), UREA (mg/dL) concentrations were measured with an autoanalyzer device (Mindray BS120 ${ }^{\circledR}$, Mindray Medical Technology Istanbul, Turkey).

\section{Statistical analyzes}

Statistical analysis of the results was performed using the SPSS ${ }^{\circledR}$ 18.0 software (SPSS Inc., Chicago, IL, USA) program. The Distribution of data in the groups was assessed using the Shapiro-Wilk test. Because the data showed parametric distribution, groups were compared by using Independent-Samples T-Test. A value of $\mathrm{P}<0.05$ was considered statistically significant.

\section{Results}

\section{Clinical examination results}

Diarrhea-induced dehydration was determined in the clinical examination findings. The degree of dehydration was determined between about 7-10 percent, where the eyes collapsed into orbit. Pulse and respiratory rate per minute were higher in the diarrheal group $(148 \pm 6.27$ and $46 \pm 2.18)$ compared to the control $(96 \pm$ 2.76 and $28 \pm 0.91$ ). In addition, the mean rectal temperature (38.8 \pm 0.89 ) was determined close to the control $(38.5 \pm 0.18)$ group. In the physical examination findings, it was determined that the conjunctiva and mucous membranes were pale and the structure of the hair was mixed.

\section{Biochemical results}

The findings showed that TAC and TOC concentrations were affected by clinical diarrhea. Thus, it increased the oxidative stress index (OSI) ( $\mathrm{p}<0.001$ ) (Figure 1). Also, the ALT, AST, CREA, and UREA levels of diarrheal calves were found to be significantly higher than the levels of healthy calves (Figure 2). 
TAC

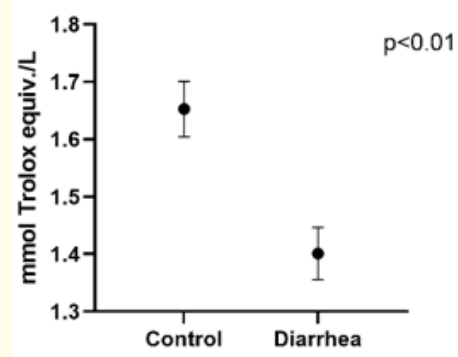

TOC

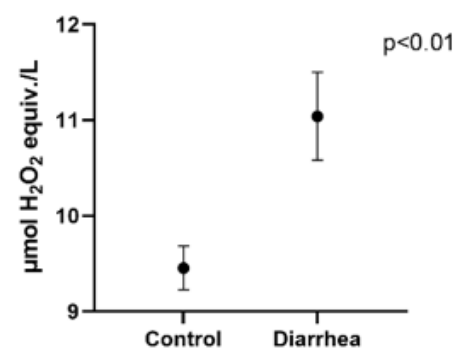

OSI

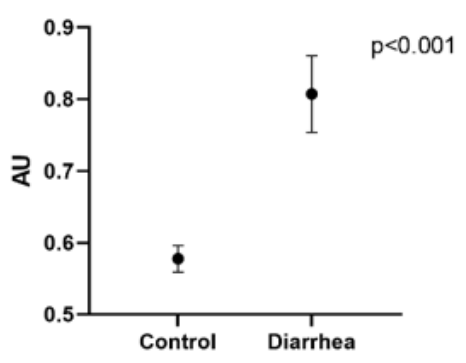

Figure 1: Oxidative stress markers. TAC: Total antioxidant capacity, TOC: Total oxidant capacity, OSI: Oxidative stress index.
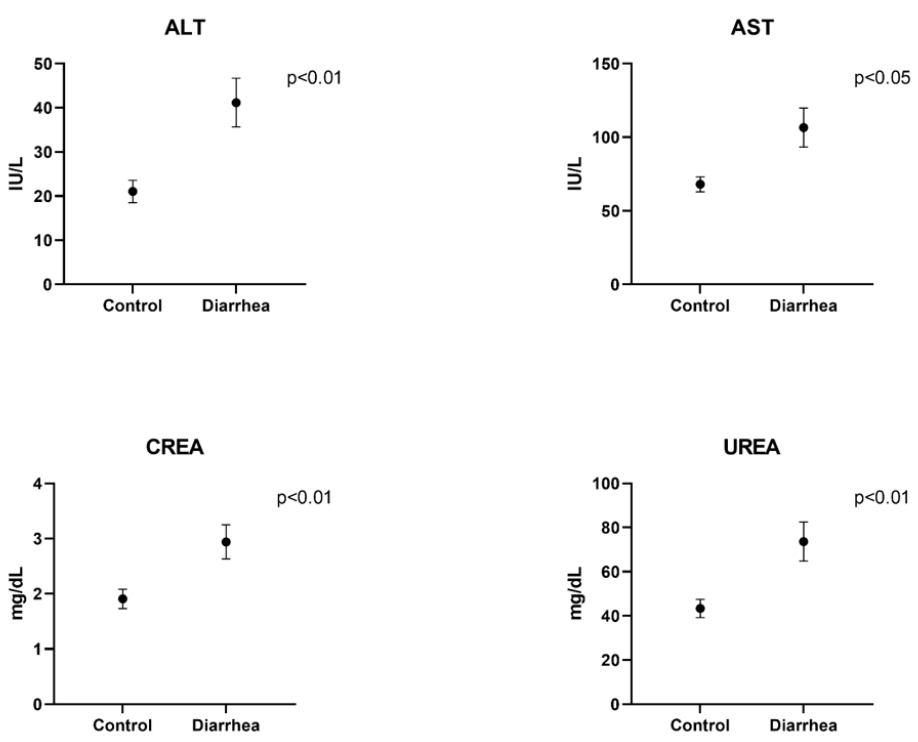

Figure 2: Liver and kidney function indicators. ALT: Alanine aminotransferase, AST: Aspartate aminotransferase, CREA: Creatinine.

\section{Discussion and Conclusion}

Oxidative agents and antioxidant mechanisms are in balance in the organism under physiological conditions. The relationship between them is disrupted as a result of the increase of free radicals or the decrease of antioxidants, causing oxidative stress and oxidative damage. It has been reported that oxidative stress and oxidative damage have a role in the pathogenesis and progression of many known diseases [17-25]. It has been reported that oxidative stress plays an important role in the pathogenesis of many diseases seen in farm animals [26]. Antioxidants are defined as substances that, when present in low concentrations, significantly inhibit or delay oxidative processes while oxidizing themselves, usually in relation to oxidizable substrates. They neutralize free radicals and oxidize themselves by accepting highly reactive unpaired electrons [10,27-29]. It has been indicated by experimental evidence that varied antioxidants play an important role against oxidants in many studies [30-38]. 
The results of the presented study showed that diarrhea caused oxidative stress in calves with diarrhea. In this study, TAC levels decreased, while TOC levels increased. As a result, the oxidative stress index increased. In many studies, it has been reported that oxidative stress occurs in diarrhea and septicemia that develops as a result [39-41]. When cells are exposed to oxidative stress, they increase the activity and expression of antioxidant enzymes to protect them from damage caused by free radicals [42]. The number of free radicals produced can be so high that even the increased activity of antioxidant enzymes is insufficient to prevent oxidative damage. As a result, antioxidants are reduced.

Due to diarrhea, severe fluid loss occurs in the body. However, loss of appetite and decreased water intake can cause the condition to progress to sepsis. Kidney functions deteriorate due to excessive fluid loss and sepsis. As a result, serum CREA and UREA values, which are important indicators of kidney function, increase $[43,44]$. In our study, serum CREA and UREA levels were found to be higher in calves with diarrhea compared to healthy calves, in line with the literature. It was evaluated that this may have been caused by the decrease in the amount of blood going to the kidneys. In addition, high serum urea and creatinine values in the diarrhea group were considered as a result of dehydration.

It has been reported in many studies that serum ALT and AST values increase in neonatal calves with diarrhea symptoms $[43,45]$. In this study, in accordance with the literature, serum ALT and AST levels were found to be higher in the diarrhea group than in the control group. It is thought that the reason why serum ALT and AST values are higher than healthy calves is due to the deterioration of intestinal and liver functions due to diarrhea.

In conclusion, in this study, it was evaluated that diarrhea significantly decreased total antioxidant levels and increased total oxidant levels in neonatal calves. This caused oxidative stress, which we can see from the increase in OSI levels. It has also been observed that liver and kidney functions are impaired due to diarrhea.

\section{Bibliography}

1. Meganck V., et al. "Evaluation of a protocol to reduce the incidence of neonatal calf diarrhoea on dairy herds". Preventive Veterinary Medicine 118.1 (2015): 64-70.

2. Erdoğan HM., et al. "Dairy farming in Kars district, Turkey: III. Neonatal calf health". Turkish Journal of Veterinary And Animal Sciences 33.3 (2009): 185-192.
3. Erkiliç EE., et al. "Salivary and serum levels of serum amyloid A, haptoglobin, ceruloplasmin and albumin in neonatal calves with diarrhoea". Kafkas Universitesi Veteriner Fakultesi Dergisi 25.4 (2019): 583-586.

4. Akyüz E., et al. "The effects of fluid resuscitation on the hemodynamic parameters of experimental induced endotoxemia in the neonatal calves". Eurasian Journal of Veterinary Sciences 32.4 (2016): 246-254.

5. Cho Y., et al. "An overview of calf diarrhea - infectious etiology, diagnosis, and intervention". Journal of Veterinary Science 15.1 (2014): 1-17.

6. Akyüz E. "Kars Bölgesindeki Neonatal Buzağılarda Sıklıkla Karşılașılan İshal Kaynaklı Sepsis Nedenleri”. Tüm Yönleri İle Kuzey Doğu Anadolu Bölgesinde Hayvancılık (2020): 401-423.

7. Aydogdu U., et al. "Effect of combinations of intravenous smallvolume hypertonic sodium chloride, acetate Ringer, sodium bicarbonate, and lactate Ringer solutions along with oral fluid on the treatment of calf diarrhea". Polish Journal of Veterinary Sciences 21.2 (2018): 273-280.

8. Akyüz E., et al. "Neonatal Buzağı İshalleri ve Sepsis". Kafkas University Institute of Natural and Applied Science Journal 10 (2017): 181-191.

9. Kükürt A., et al. "Nitrik oksit, nitrik oksit sentaz ve dişi üreme sistemindeki rolleri". In: Evereklioğlu C, editor. Sağlık Bilimleri Alanında Akademik Çalışmalar II (2020) 113-123.

10. Kükürt A., et al. "Thiols: Role in Oxidative Stress-Related Disorders". Lipid Peroxidation (2021).

11. Kükürt A., et al. "Kisspeptin: Role in Female Infertility". In: Marsh C, editor. Reproductive Hormones (2021).

12. Kükürt A.,"Doğal bir antioksidan olarak propolis tedavisinin koruyucu etkileri”. In: Evereklioğlu C, editor. Sağlık Bilimlerinde Teori ve Araştırmalar II (2020): 501-515.

13. Kuru M., et al. "Clinical Use of Progesterone and Its Relation to Oxidative Stress in Ruminants". In: Drevenšek G, editor. Sex Hormones in Neurodegenerative Processes and Diseases. (2018): 303-327.

14. Erel 0. "A novel automated direct measurement method for total antioxidant capacity using a new generation, more stable ABTS radical cation". Clinical Biochemistry 37 (2004): 277285. 
15. Erel 0. "A new automated colorimetric method for measuring total oxidant status". Clinical Biochemistry 38 (2005): 11031111.

16. Kaya I., et al. "Investigation of Serum Oxidative Stress Index and Paraoxonase Activity Levels in Colostrum Period of Dairy Cows". International Journal of Livestock Research 6 (2016): 1-7.

17. Miller JK., et al. "Oxidative Stress, Antioxidants, and Animal Function”. Journal of Dairy Science 76.9 (1993): 2812-2823.

18. Kirmizigül AH., et al. "Oxidative stress and total sialic acid levels in sheep naturally infected with pox virus" Pakistan Veterinary Journal 36.3 (2016): 312-315.

19. Deveci HA., et al. "Serum paraoxonase activity and total sialic acid in sheep with foot and mouth disease". Medycyna weterynaryjna 74.3 (2018): 199-202.

20. Merhan O., et al. "Investigation of Oxidative Stress Index and Lipid Profile in Cattle with Brucellosis". Kafkas Universitesi Veteriner Fakultesi Dergisi 26.6 (2017): 933-937.

21. Kaya S., et al. "The Impact of Endometritis on Specific Oxidative Stress Parameters in Cows". Journal of the Hellenic Veterinary Medical Society 68.2 (2017): 231-236.

22. Deveci HA., et al. "Evaluation of paraoxonase activity, total sialic acid and oxidative stress in sheep with ecthyma contagiosa". Kafkas Üniversitesi Veteriner Fakültesi Dergisi 23.3 (2017): 453-457.

23. Erkiliç EE., et al. "Determination of some Oxidative Stress and Inflammation Markers in Serum, Blood and CSF in Cattle with Head-Eye Form of Malignant Catarrhal Fever". Kafkas Üniversitesi Veteriner Fakültesi Dergisi 23.4 (2017): 515-519.

24. Deveci H.A., et al. "Biochemical and Histopathological Changes of Babesiosis in Naturally Infected Sheep in Gaziantep Region". Fresenius Environmental Bulletin 26 (2017): 4883-4889.

25. Deveci HA., et al. "Determination of Serum Paraoxonase Activity, Total Sialic Acid Concentration, and Oxidative Status in Cattle with Clinical Mastitis". International Journal of Veterinary Science 6.3 (2017): 136-140.

26. Lykkesfeldt J., et al. "Oxidants and antioxidants in disease: Oxidative stress in farm animals". The Veterinary Journal 173.3 (2007): 502-511.
27. Vaya J., et al. "Nutritional Antioxidants Mechanisms of Action, Analyses of Activities and Medical Applications". Current Medicinal Chemistry - Immunology, Endocrine and Metabolic Agents 1 (2001): 99-117.

28. Halliwell B., et al. "Free Radicals in Biology and Medicine". Free Radical Biology and Medicine (2015).

29. Akyüz E., et al. "The Determination of Oxidative Stress Index of Enteritis Caused by Escherichia coli K99 Strain in Simmental New-born Calves". International Turkish Veterinary Internal Medicine Congress (2017): 176-177.

30. Gelen V., et al. "The protective effects of hesperidin and curcumin on 5-fluorouracil-induced nephrotoxicity in mice". Environmental Science and Pollution Research (2021): 1-10.

31. Kaya I., et al. "Effect of ellagic acid on some oxidative stress parameters and cyclooxygenase- 2 reactivity in mice with experimental gastric injury". Japanese Journal of Gastroenterology and Hepatology 2.3 (2019): 1-9.

32. Kaya I., et al. "Investigation of oxidative stress index in pyridine and ellagic acid treated mice". Eurasian Journal of Veterinary Sciences 31.3 (2015): 148-151.

33. Deveci HA., et al. "Akut klorprifos-etil toksikasyonunda kafeik asit fenetil esterin total sialik asit, nitrik oksit ve aminotransferaz düzeylerine etkisi”. Kafkas Üniversitesi Fen Bilimleri Enstitüsü Dergisi 9.1 (2016): 39-45.

34. Ogun M., et al. "Oleuropein ameliorates arsenic induced oxidative stress in mice". Journal of Trace Elements in Medicine and Biology 36 (2016): 1-6.

35. Deveci HA., et al. "Protective role of caffeic acid phenethyl ester against to chlorpyrifos-ethyl acute poisoning". Ankara Üniversitesi Veteriner Fakültesi Dergisi 62.4 (2015): 255-260.

36. Karapehlivan M., et al. "The beneficial effects of silymarin administration against nicotine induced oxidative stress in mice". Journal of Cellular Neuroscience and Oxidative Stress 8.1 (2016): 561.

37. Deveci HA., et al. "Protective Effect of Caffeic Acid Phenethyl Ester on Cadmium-Induced Liver Toxicity: A Histopathological and Biochemistry Study". PREPRINT (Version 1) available at Research Square [https://doi.org/10.21203/rs.3.rs-675811/ v1] (2021): 1-15. 
38. Kükürt A. "In vivo antioxidative activities of ellagic acid in indomethacin-induced gastric injury related oxidative stress". Journal of Cellular Neuroscience and Oxidative Stress (2021).

39. Meral Ö., et al. "Septisemili buzağllarda lipid peroksidasyon düzeyi ve antioksidan enzim aktiviteleri”. Ankara Üniversitesi Veteriner Fakültesi Dergisi 64 (2017): 161-164.

40. Erkilic EE., et al. "Relationship between hepcidin and oxidant/ antioxidant status in calves with suspected neonatal septicemia”. Veterinary World 9 (2016): 1238-1241.

41. Kabu M., et al. "Determination of pre and post treatment oxidative status and oxidative DNA damage in diarrheic calves". Indian Journal of Animal Research 49.6 (2015): 830-833.

42. Rodriguez C., et al. "Regulation of antioxidant enzymes: A significant role for melatonin". Journal of Pineal Research 36.1 (2004): 1-9.

43. Akyüz E., et al. "Neopterin, procalcitonin, clinical biochemistry, and hematology in calves with neonatal sepsis". Tropical Animal Health and Production 53 (2021).

44. Dratwa-Chałupnik A., et al. "Calves with diarrhea and a waterelectrolyte balance". Medycyna Weterynaryjna 68.1 (2012): 65-72.

45. Albayrak H., et al. "Determining Serum Haptoglobin and Cytokine Concentrations in Diarrheic Calves". Firat Üniversitesi Sağlık Bilimleri Dergisi 30.2 (2016): 113-117.

Volume 3 Issue 9 September 2021

(c) All rights are reserved by Enes Akyüz and

Abdulsamed Kükürt.

Citation: Enes Akyüz and Abdulsamed Kükürt. "Evaluation of Oxidative Stress Index and Some Biochemical Parameters in Neonatal Calves with Diarrhea". Acta Scientific Veterinary Sciences 3.9 (2021): 58-63. 